\title{
Strength and Drying Shrinkage of Alkali-Activated Slag Paste and Mortar
}

\author{
Mao-chieh Chi, ${ }^{1}$ Jiang-jhy Chang, ${ }^{2}$ and Ran Huang ${ }^{2}$ \\ ${ }^{1}$ Department of Fire Science, WuFeng University, Chiayi County 62153, Taiwan, China \\ ${ }^{2}$ Department of Harbour and River Engineering, National Taiwan Ocean University, Keelung 20224, Taiwan, China
}

Correspondence should be addressed to Jiang-jhy Chang, jjc@mail.ntou.edu.tw

Received 9 January 2012; Accepted 14 March 2012

Academic Editor: Venu Gopal Madhav Annamdas

Copyright () 2012 Mao-chieh Chi et al. This is an open access article distributed under the Creative Commons Attribution License, which permits unrestricted use, distribution, and reproduction in any medium, provided the original work is properly cited.

\begin{abstract}
The aim of this study is to investigate the strengths and drying shrinkage of alkali-activated slag paste and mortar. Compressive strength, tensile strength, and drying shrinkage of alkali-activated slag paste and mortar were measured with various liquid/slag ratios, sand/slag ratios, curing ages, and curing temperatures. Experimental results show that the higher compressive strength and tensile strength have been observed in the higher curing temperature. At the age of 56 days, AAS mortars show higher compressive strength than Portland cement mortars and AAS mortars with liquid/slag ratio of 0.54 have the highest tensile strength in all AAS mortars. In addition, AAS pastes of the drying shrinkage are higher than AAS mortars. Meanwhile, higher drying shrinkage was observed in AAS mortars than that observed comparable Portland cement mortars.
\end{abstract}

\section{Introduction}

Alkali-activated slag (AAS) has a great potential for using industrial byproducts. The production of AAS concretes is associated with low energy consumption and low $\mathrm{CO}_{2}$ emission. The alkaline activation of slag has been studied [16]. Its main reaction product is a low-crystalline hydrated calcium silicate. When compared with Portland cements and concretes, AAS cements and concretes present several advantages, such as earlier and higher strengths, lower hydration heat, and stronger resistance to chemical attack. However, they also have some disadvantages, such as quick setting and high shrinkage rate with formation of microcracking [7].

The strength development and drying shrinkage of AAS are determined by the nature of the compounds forming during the activation and curing process [8]. Collins and Sanjayan [9] examined the effects of internal curing of AAS concrete by replacing normal weight coarse aggregate with fully saturated slag coarse aggregate and showed that the compressive strength was improved and the drying shrinkage was less. Puertas et al. [7] found that the nature of the matrix is the most important factor to the strength development. Krizan and Zivanovic [10] reported that the compressive strength of normal-cured water glass slag cements is higher than that of Portland cement mortars and drying shrinkage of alkali-slag cements is also higher than that of Portland cement. Bakharev et al. [11] studied the effect of elevated curing temperature on properties of AAS concrete and concluded that heat treatment greatly accelerates strength development, but at later ages the compressive strength was reduced compared to concrete cured at room temperature. In addition, heat curing considerably reduces shrinkage of AAS concrete. Fernández-Jiménez et al. [3] studied the flexural and compressive strengths of AAS mortars and reported that liquid sodium silicate gave the highest strengths. The factors influencing the flexural and compressive strengths were the concentration of the activator, followed by curing temperature, and the fineness of the slag.

The composition of slag depends on the raw materials and the industrial products; thus, each slag differs in response to activation [4]. Meanwhile, many researches on the compressive strength and shrinkage of AAS mortars and concretes were published. However, there is insufficient data on tensile strength, and particularly the effect of various sand/ slag ratios on the strength and shrinkage of AAS mortars and concretes has not been previously reported. Therefore, one of the aims of this study is to investigate and provide more data on the tensile strength. Another aim of this study is to 
TABLE 1: Chemical composition of granulated blast furnace slag and cement (\%wt).

\begin{tabular}{lcc}
\hline Physical properties/chemical compositions & GBFS & OPC \\
\hline Calcium oxide, $\mathrm{CaO}$ & 39.54 & 63.56 \\
Silicon dioxide, $\mathrm{SiO}_{2}$ & 33.87 & 21.04 \\
Aluminum oxide, $\mathrm{Al}_{2} \mathrm{O}_{3}$ & 14.42 & 5.46 \\
Ferric oxide, $\mathrm{Fe}_{2} \mathrm{O}_{3}$ & 0.69 & 2.98 \\
Sulfur trioxide, $\mathrm{SO}_{3}$ & 2.47 & 2.04 \\
Sodium oxide, $\mathrm{Na}_{2} \mathrm{O}$ & 0.48 & 0.32 \\
Potassium oxide, $\mathrm{K}_{2} \mathrm{O}$ & 0.65 & 0.70 \\
Magnesium oxide, $\mathrm{MgO}$ & 5.35 & 2.52 \\
Loss on ignition, L.O.I. & 2.53 & 1.38 \\
\hline
\end{tabular}

develop a better of understanding the effects of liquid/slag ratios, sand/slag ratios, curing ages, and curing temperatures on the strength and shrinkage of AAS pastes and mortars.

\section{Experimental Programs}

2.1. Materials. The chemical composition of GBFS used in this work is shown in Table 1 . The basicity coefficient $K_{b}=$ $(\mathrm{CaO}+\mathrm{MgO}) /\left(\mathrm{SiO}_{2}+\mathrm{Al}_{2} \mathrm{O}_{3}\right)$ and the hydration modulus $\mathrm{HM}=\left(\mathrm{CaO}+\mathrm{MgO}+\mathrm{Al}_{2} \mathrm{O}_{3}\right) / \mathrm{SiO}_{2}$ based on the chemical composition were 0.93 and 1.75 , respectively. Its specific gravity and Blaine fineness were $2900 \mathrm{~kg} / \mathrm{m}^{3}$ and $383 \mathrm{~m}^{2} / \mathrm{kg}$, respectively. The slag activity index at 7 and 28 days was $70.36 \%$ and $104.63 \%$, respectively. The ordinary Portland cement (OPC) type I with a specific gravity of $3150 \mathrm{~kg} / \mathrm{m}^{3}$ and Blaine fineness of $364 \mathrm{~m}^{2} / \mathrm{kg}$ was used as reference binder. Its chemical composition is also shown in Table 1. The river sand as fine aggregate was used, and the specific gravity, water absorption, and the fineness modulus of fine aggregates are $2.66,2.8 \%$, and 2.72 , respectively.

The most used alkaline activators are a mixture of $\mathrm{NaOH}$ with sodium silicate $\left(\mathrm{Na}_{2} \mathrm{O} \cdot \gamma \mathrm{SiO}_{2}\right)$ [12]. In this study, the alkaline activation of the GBFS was carried out using $\mathrm{NaOH}$ pellets with a density of $2130 \mathrm{~kg} / \mathrm{m}^{3}$ and sodium silicate solution $\left(\mathrm{Na}_{2} \mathrm{O} \cdot \gamma \mathrm{SiO}_{2} \cdot n \mathrm{H}_{2} \mathrm{O}\right)$ composed of $37.0 \%$ $\mathrm{SiO}_{2}, 17.7 \% \mathrm{Na}_{2} \mathrm{O}$, and $45.3 \% \mathrm{H}_{2} \mathrm{O}$ by mass and a solution modulus $\left(M_{s}=\mathrm{SiO}_{2} / \mathrm{Na}_{2} \mathrm{O}\right)$ of 2.09 .

2.2. Mixture and Specimen Preparation. Alkali-activated slag (AAS) mortars with three liquid-to-binder ratios of 0.44 , 0.54 , and 0.64 and three levels of sand-to-binder of 0,1 , and 2 per cubic meter of mortar according to ACI recommendations were designed, respectively. The proportions by weight of ordinary Portland cement mortar mixture as a control were $1: 2: 0.54$ cement, sand, and water, respectively. $122 \mathrm{~g} / \mathrm{L}$ (gram per liter) sodium hydroxide, $123 \mathrm{~g} / \mathrm{L}$ sodium silicate, and $0.77 \mathrm{M}$ phosphoric acid solutions were blended, providing the modulus in solution (mass ratio of $\mathrm{SiO}_{2}$ to $\mathrm{Na}_{2} \mathrm{O}$ ), $M_{s}$, is equal to 1.01 , as activators for slag activation. Slag was activated by the alkaline solutions. The specimens were cast and kept in steel molds for 24 hours, and then they were demolded and then moved into a curing room until testing. For all mixtures, strengths and drying shrinkage were evaluated after cure of the temperature 23,65 , and $85^{\circ} \mathrm{C}$.

2.3. Methods. The compressive strength tests of the specimens were conducted according to ASTM C109-08. For each mixture, three $50 \times 50 \times 50 \mathrm{~mm}$ cubic specimens were prepared. The tensile strength tests were performed in accordance with ASTM C190. The flexural strength tests of prismatic specimens with $40 \times 40 \times 160 \mathrm{~mm}$ dimensions were conducted following ASTM C348. Compressive strength, tensile strength, and flexural strength of alkali-activated slag mortar were determined at the age of 3, 7, 28, and 56 days, respectively. Drying shrinkage measurement was carried out according to ASTM C596. The length $\left(L_{x}\right)$ of the shrinkage specimens was measured at the age of $3,7,14,21,28,35$, 42,49 , and 56 days, respectively. The length change was then calculated by the following formula:

$$
\text { length change : } \operatorname{LC}(\%)=\frac{L_{i}-L_{x}}{G} \times 100 \text {, }
$$

where $G$ is the nominal effective length.

For each mixture, three specimens were prepared and tested in this study.

\section{Results and Discussion}

3.1. Compressive Strength. The main hydration product found in AAS is a low-crystalline hydrated calcium silicate, like a C-S-H gel with a low calcium/silicon ratio, hydrotalcite, and ettringite or AFm phase [7, 13-16]. It is probably because of the high $\mathrm{pH}$ solutions, which favors low calcium concentrations and high silicon concentrations. The compressive strength of AAS pastes and mortars with various curing temperatures and sand/slag ratios is presented in Figures 1, 2 and 3. The compressive strength of the Portland cement mortars is presented in Table 2. The compressive strength of AAS pastes and mortars increases as the curing age increases. The effect of curing temperature on AAS pastes and mortars was investigated further. Heat curing for $12 \mathrm{hr}$ at $65^{\circ} \mathrm{C}$ and for $6 \mathrm{hr}$ at $85^{\circ} \mathrm{C}$ produced considerable acceleration in compressive strength development. Compressive strength is quickly growing with an increase of curing temperature at the age of 3 days. However, at 7 days and beyond, the compressive strength of AAS mortars with 65 and $85^{\circ} \mathrm{C}$ curing is slow growing or levels off, whereas AAS mortars cured at $23^{\circ} \mathrm{C}$ continue to gain strength with ages. Between 28 and 56 days, the compressive strength of AAS mortars cured at $23^{\circ} \mathrm{C}$ is almost close to that of AAS mortars cured at 65 and $85^{\circ} \mathrm{C}$. Moreover, the strength of AAS mortars with liquid/slag ratio of 0.44 cured at $23^{\circ} \mathrm{C}$ exceeds values for AAS mortars cured at 65 and $85^{\circ} \mathrm{C}$. Bakharev et al. [4] reported that when curing temperature is used, it leads to a strength increase in alkali-activated slag for the initial curing times but with a decrease for older times. Other authors [17] also noticed a strength decrease for long curing time with temperature. At the age of 56 days, the compressive strength of AAS mortars with $65^{\circ} \mathrm{C}$ curing is higher than that with 


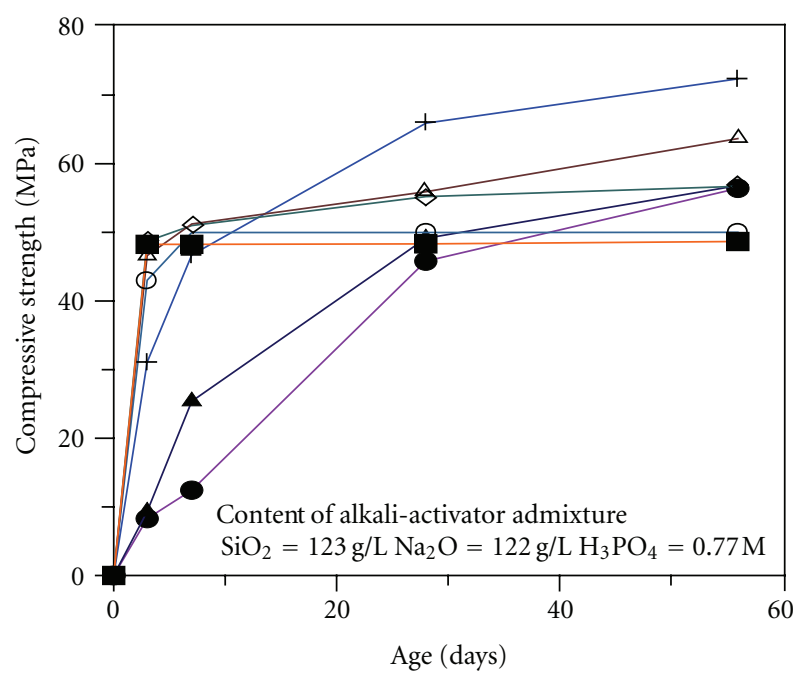

\footnotetext{
Liquid $/$ slag $=0.44$

+ Temperature $23^{\circ} \mathrm{C}$ sand $/$ slag $=0$

- Temperature $23^{\circ} \mathrm{C}$ sand $/$ slag $=1$

_ـ Temperature $23^{\circ} \mathrm{C}$ sand $/$ slag $=2$

$\diamond$ Temperature $65^{\circ} \mathrm{C}$ sand $/$ slag $=1$

$\bigcirc$ Temperature $65^{\circ} \mathrm{C}$ sand $/ \mathrm{slag}=2$

$\triangle$ Temperature $85^{\circ} \mathrm{C}$ sand $/$ slag $=1$

- Temperature $85^{\circ} \mathrm{C}$ sand $/$ slag $=2$
}

FIGURE 1: Compressive strength of AAS mortars $(L / S=0.44)$.

TABle 2: Compressive strength of Portland cement mortars at water/cement ratio of $0.54(\mathrm{MPa})$.

\begin{tabular}{|c|c|c|}
\hline Group & PC (Portland cement) & $\begin{array}{c}\text { APC (alkali-activated } \\
\text { Portland cement) }\end{array}$ \\
\hline $\begin{array}{l}\text { Curing } \\
\text { temperature }\left({ }^{\circ} \mathrm{C}\right)\end{array}$ & & ( \\
\hline Sand/slag ratio & & 2 \\
\hline 3 days & 12.45 & 22.20 \\
\hline 7 days & 21.52 & 25.30 \\
\hline 28 days & 32.46 & 30.10 \\
\hline 56 days & 39.25 & 34.20 \\
\hline
\end{tabular}

$85^{\circ} \mathrm{C}$ curing except the AAS mortar with liquid/slag ratio of 0.44 and sand/slag ratio of 1 .

Figure 4 shows the compressive strength of AAS mortars with various liquid/slag ratios and sand/slag ratios at the age of 56 days. It can be seen that the compressive strength of AAS mortars decreases with an increase in liquid/slag ratio. In addition, the compressive strength of AAS mortars also decreases with an increase in sand/slag ratio and AAS mortars show higher compressive strength than Portland cement mortars and alkali-activated Portland cement mortars. The compressive strength of alkali-activated binder is higher than that of fine aggregate. Thus, a higher ratio of sand would lead to lower compressive strength for AAS mortars.

3.2. Tensile Strength. The tensile strength of AAS pastes and mortars with various curing temperatures and sand/slag

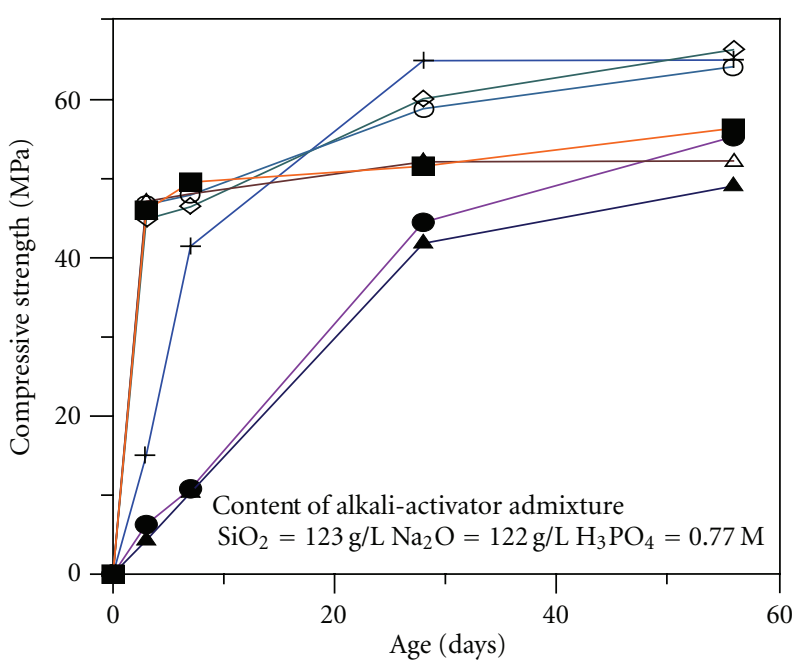

$$
\begin{aligned}
& \text { Liquid/slag }=0.54 \\
& -\quad \text { Temperature } 23^{\circ} \mathrm{C} \text { sand } / \text { slag }=0 \\
& -\quad \text { Temperature } 23^{\circ} \mathrm{C} \text { sand } / \text { slag }=1 \\
& -\quad \text { Temperature } 23^{\circ} \mathrm{C} \text { sand } / \text { slag }=2 \\
& \triangle \quad \text { Temperature } 65^{\circ} \mathrm{C} \text { sand } / \text { slag }=1 \\
& -\quad \text { Temperature } 65^{\circ} \mathrm{C} \text { sand } / \text { slag }=2 \\
& \triangle \quad \text { Temperature } 85^{\circ} \mathrm{C} \text { sand } / \text { slag }=1 \\
& -\quad \text { Temperature } 85^{\circ} \mathrm{C} \text { sand } / \text { slag }=2
\end{aligned}
$$

FIGURE 2: Compressive strength of AAS mortars $(L / S=0.54)$.

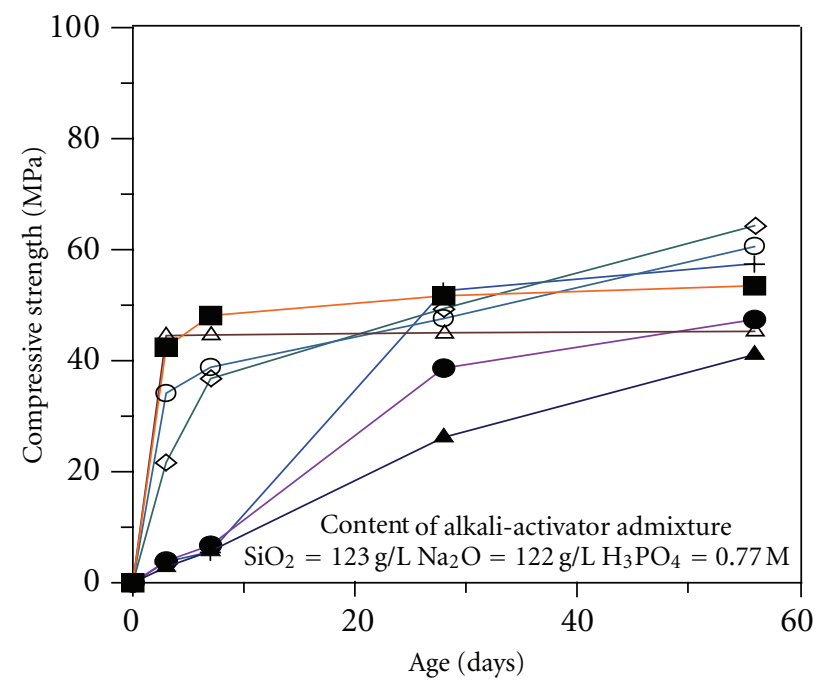

$$
\begin{aligned}
& \text { Liquid } / \text { slag }=0.64 \\
& \text { + Temperature } 23^{\circ} \mathrm{C} \text { sand } / \mathrm{slag}=0 \\
& \text { - } \quad \text { Temperature } 23^{\circ} \mathrm{C} \text { sand } / \text { slag }=1 \\
& \text { —- Temperature } 23^{\circ} \mathrm{C} \text { sand } / \mathrm{slag}=2 \\
& \diamond \text { Temperature } 65^{\circ} \mathrm{C} \text { sand } / \text { slag }=1 \\
& \bigcirc \text { Temperature } 65^{\circ} \mathrm{C} \text { sand } / \text { slag }=2 \\
& \triangle \text { Temperature } 85^{\circ} \mathrm{C} \text { sand } / \text { slag }=1 \\
& \text { - Temperature } 85^{\circ} \mathrm{C} \text { sand } / \text { slag }=2
\end{aligned}
$$

Figure 3: Compressive strength of AAS mortars $(L / S=0.64)$. 


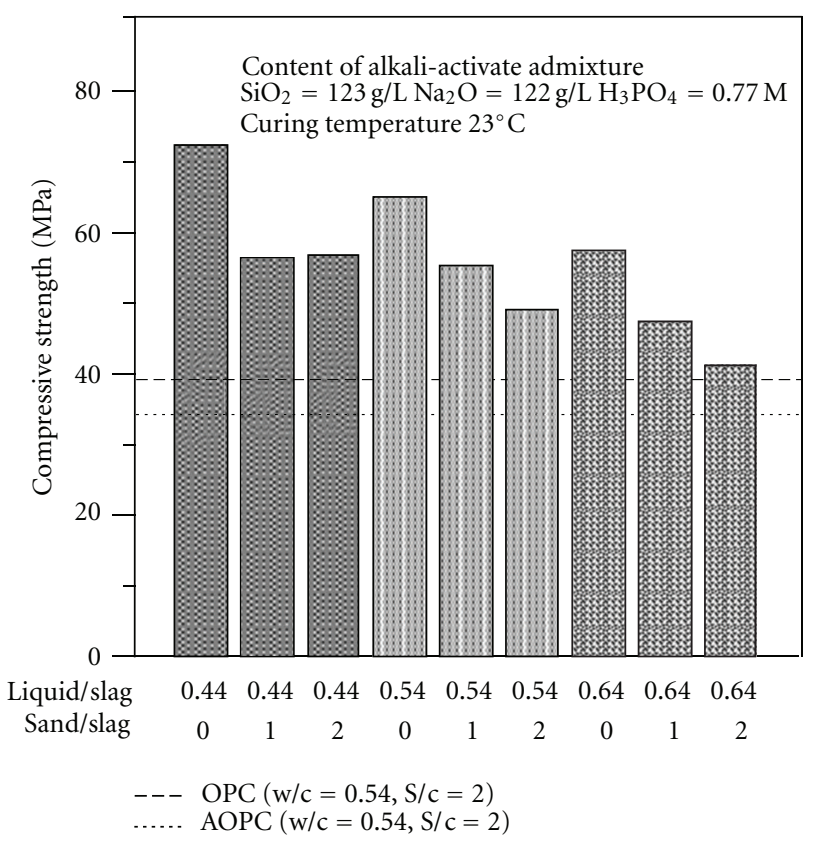

Figure 4: Compressive strength of AAS mortars at the age of 56 days.

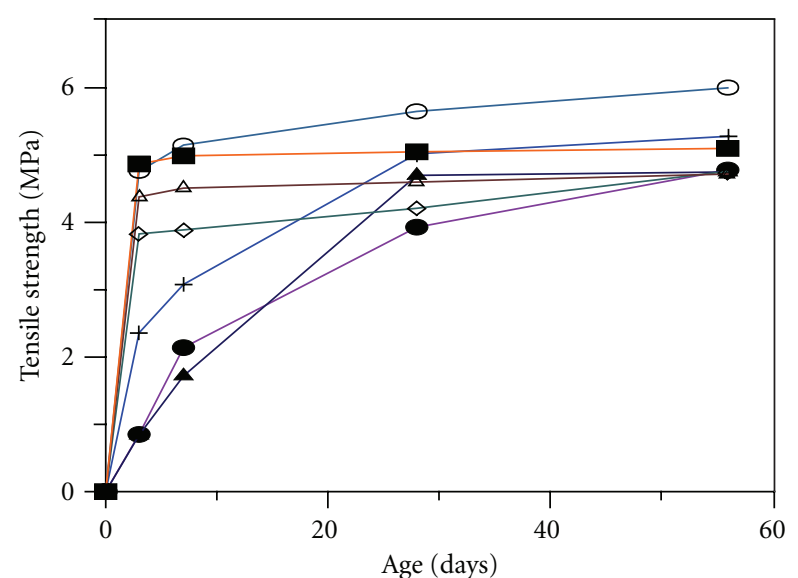

Content of Liquid/slag $=0.44$

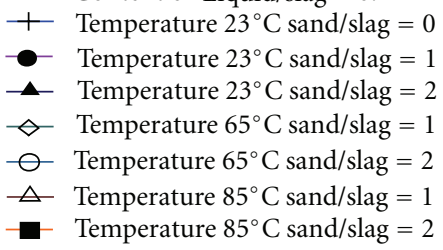

Figure 5: Tensile strength of AAS mortars $(L / S=0.44)$.

ratios is presented in Figures 5, 6 and 7. The tensile strength of Portland cement mortars is presented in Table 3. Similar findings to compressive strength were found for tensile strength of AAS pastes and mortars. AAS mortars with heat curing for $12 \mathrm{hr}$ at $65^{\circ} \mathrm{C}$ and for $6 \mathrm{hr}$ at $85^{\circ} \mathrm{C}$ show higher tensile strength than the other AAS mortars cured at $23^{\circ} \mathrm{C}$ at 3 and 7 days. After 28 days, the tensile strength of AAS
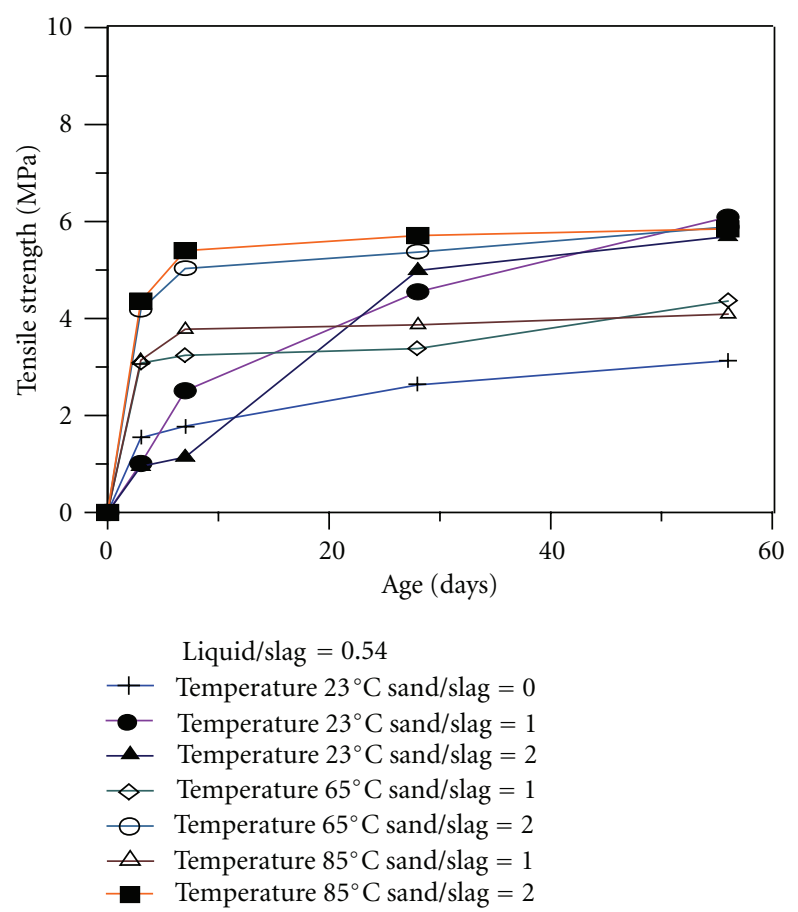

Figure 6: Tensile strength of AAS mortars $(L / S=0.54)$.

TABLE 3: Tensile strength of Portland cement mortars at water/cement ratio of $0.54(\mathrm{MPa})$.

\begin{tabular}{lcc}
\hline Group & PC (Portland cement) & $\begin{array}{c}\text { APC (alkali-activated } \\
\text { Portland cement) }\end{array}$ \\
\hline $\begin{array}{l}\text { Curing } \\
\text { temperature }\left({ }^{\circ} \mathrm{C}\right)\end{array}$ & 23 \\
sand/slag ratio & & 2 \\
3 days & 2.02 & 2.80 \\
7 days & 3.68 & 3.57 \\
28 days & 4.40 & 4.25 \\
56 days & 4.77 & 4.76 \\
\hline
\end{tabular}

mortars cured at 65 and $85^{\circ} \mathrm{C}$ is slow growing or levels off, whereas AAS mortars cured at $23^{\circ} \mathrm{C}$ continue to gain tensile strength with ages. At the age of 56 days, AAS mortars of liquid/slag ratio of 0.54 and sand/slag ratio of 1 at $23^{\circ} \mathrm{C}$ curing have the highest tensile strength. However, the effect of curing temperature on AAS mortars is limited. As the curing temperature increases from $65^{\circ} \mathrm{C}$ to $85^{\circ} \mathrm{C}$, the tensile strength of AAS mortars has a slow drop. In addition, at the same liquid/slag ratio, the tensile strength of AAS mortars with sand/slag ratio of 2 is higher than that of AAS mortars with sand/slag ratio of 1 at 65 and $85^{\circ} \mathrm{C}$ curing.

Figure 8 shows the tensile strength of AAS mortars cured at $23^{\circ} \mathrm{C}$ with various liquid/slag ratios and sand/slag ratios at the age of 56 days. It can be seen that the AAS mortars with liquid/slag ratio of 0.54 have the highest tensile strength compared to the other AAS mortars, followed by the liquid/slag ratio of 0.44 and 0.64 . Meanwhile, the ratio of the tensile strength of AAS mortar with the liquid/slag ratio of 


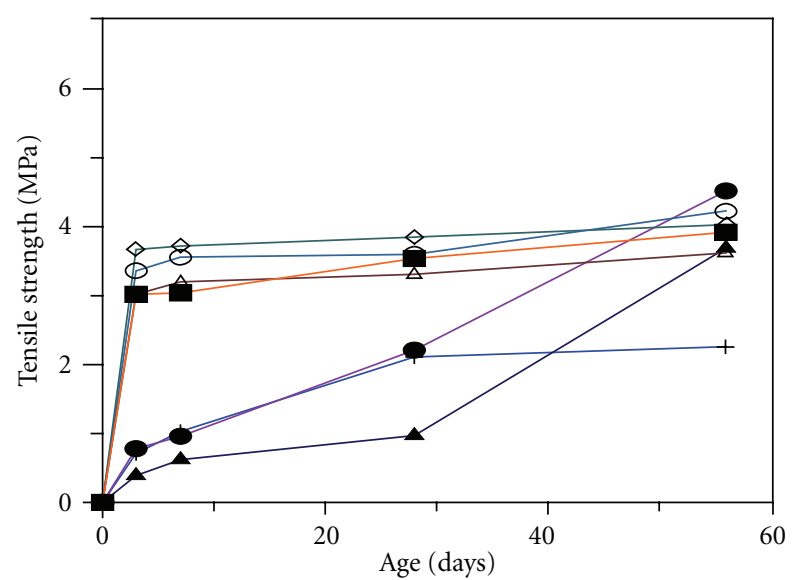

Liquid/slag $=0.64$

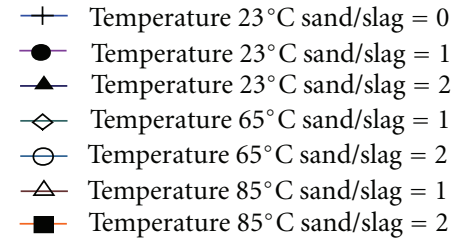

Figure 7: Tensile strength of AAS mortars $(L / S=0.64)$.

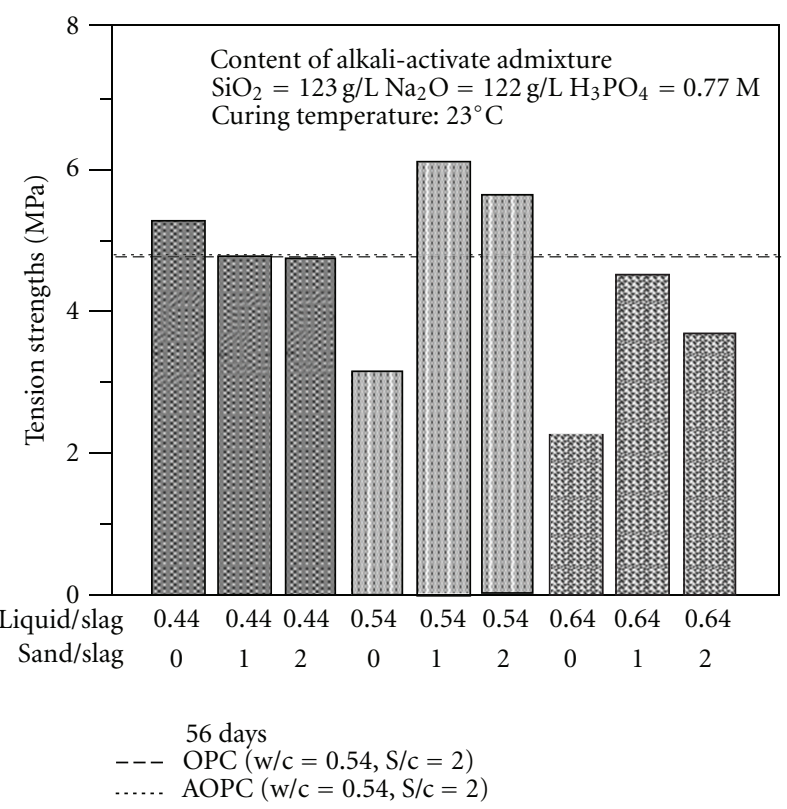

FIGURE 8: Tensile strength of AAS mortars at the age of 56 days.

0.54 to that of the Portland cement mortar is 1.2. In general, the lower liquid/slag ratio leads to the lower workability. Therefore, it can be explained that the lower workability decreases the cohesion strength of transition zone, thus, causing a reduction in the tensile strength. On the other hand, the tensile strength of AAS pastes decreases with an increase of liquid/slag ratio. The higher liquid/slag ratio leads to the lower alkali-activated reaction.
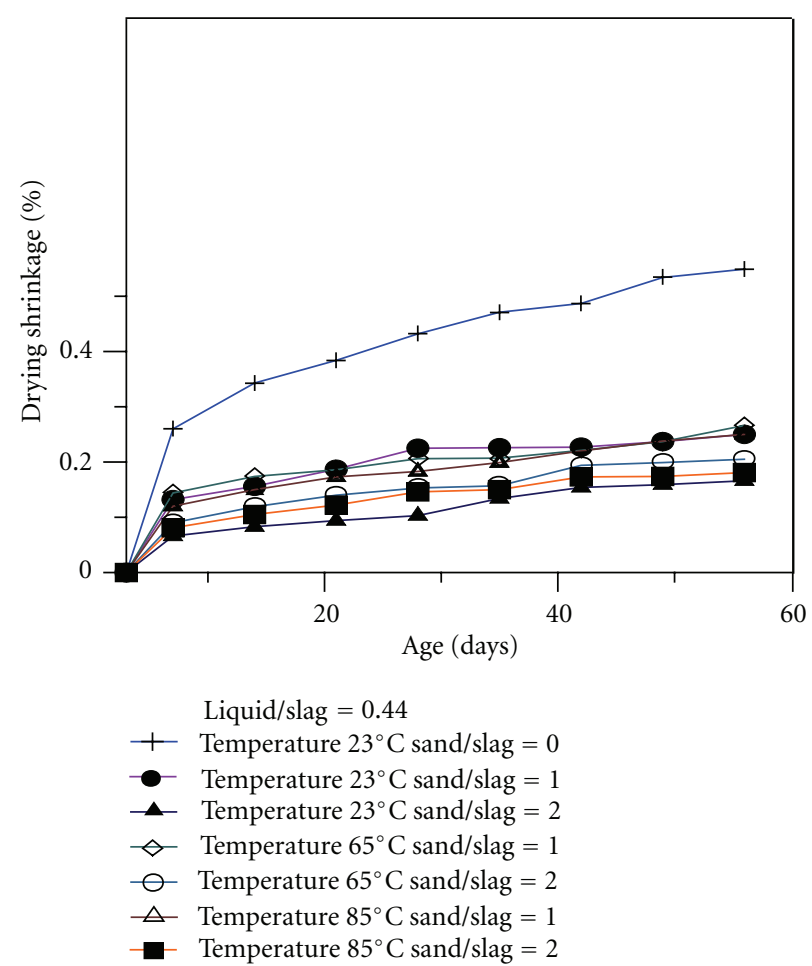

Figure 9: Drying shrinkage of AAS mortars $(L / S=0.44)$.

3.3. Drying Shrinkage. The drying shrinkage of the AAS pastes and mortars with various curing temperatures and sand/slag ratios is presented in Figures 9, 10, 11. The drying shrinkage of Portland cement mortars is listed in Table 4. Most of the drying shrinkage takes place during the early ages. AAS pastes of the drying shrinkage are higher than AAS mortars. Meanwhile, the drying shrinkage of pastes and mortars increases with an increase of liquid/slag ratio. The liquid/slag ratio determines the amount of evaporable water in the paste and the rate at which water can move towards the surface of the specimen. Thus, the amount of alkaline solution greatly influences mechanical properties, porosity, and the degree of hydration, which are determining factors for the development of shrinkage [5]. The increase of water content caused the increase of drying shrinkage. However, water content is not a primary factor influencing drying shrinkage. The higher sand/slag ratio results in the lower drying shrinkage. Reducing the amount of paste and lowering the liquid/slag ratio have a positive effect on drying shrinkage of AAS pastes and mortars. In addition, the higher curing temperature leads to a lower drying shrinkage. The greater the quantity of hydrated products the smaller the volume of unhydrated cement particles that restrain the shrinkage.

Figure 12 shows the drying shrinkage of AAS and Portland cement mortars. It can be seen that higher drying shrinkage was observed in AAS mortars than that observed in comparable Portland cement mortars. Collins and Sanjayan [18] reported that the mechanism of high drying shrinkage of AAS concrete is not absolutely owing to the quantity 


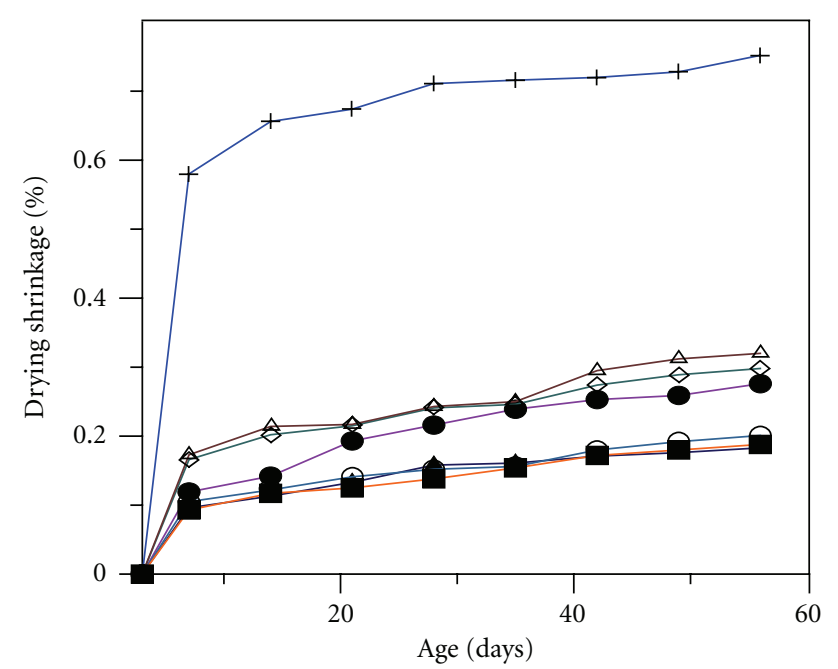

Liquid/slag $=0.54$

+ Temperature $23^{\circ} \mathrm{C}$ sand $/$ slag $=0$

- Temperature $23^{\circ} \mathrm{C}$ sand $/$ slag $=1$

- Temperature $23^{\circ} \mathrm{C}$ sand $/$ slag $=2$

$\diamond$ Temperature $65^{\circ} \mathrm{C}$ sand $/$ slag $=1$

- Temperature $65^{\circ} \mathrm{C}$ sand $/$ slag $=2$

$\triangle$ Temperature $85^{\circ} \mathrm{C}$ sand $/$ slag $=1$

- Temperature $85^{\circ} \mathrm{C}$ sand $/$ slag $=2$

FIgURE 10: Drying shrinkage of AAS mortars $(L / S=0.54)$.

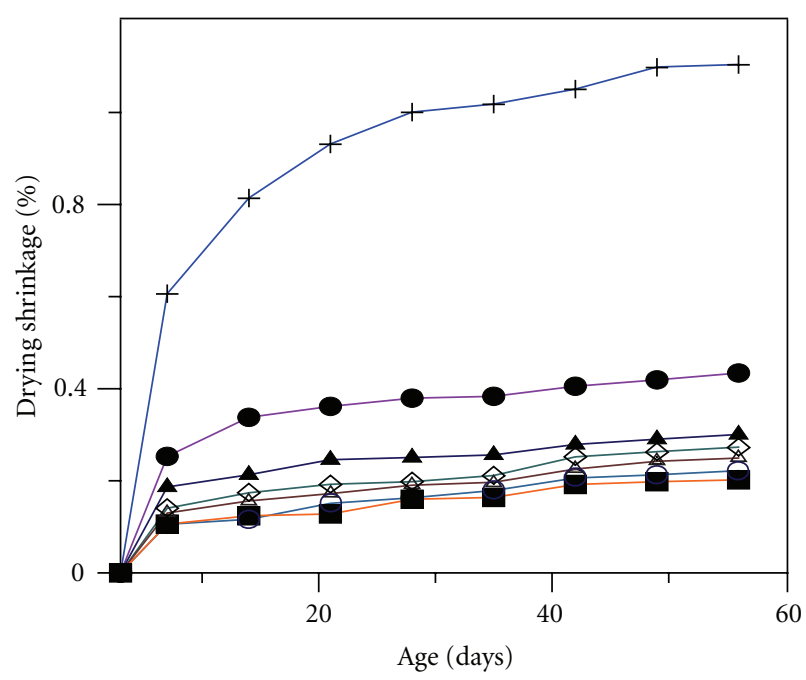

Liquid/slag $=0.64$

+ Temperature $23^{\circ} \mathrm{C}$ sand $/$ slag $=0$

- $\quad$ Temperature $23^{\circ} \mathrm{C}$ sand $/$ slag $=1$

- Temperature $23^{\circ} \mathrm{C}$ sand $/$ slag $=2$

$\diamond$ Temperature $65^{\circ} \mathrm{C}$ sand $/$ slag $=1$

$\bigcirc$ Temperature $65^{\circ} \mathrm{C}$ sand $/$ slag $=2$

$\triangle$ Temperature $85^{\circ} \mathrm{C}$ sand $/$ slag $=1$

- Temperature $85^{\circ} \mathrm{C}$ sand $/$ slag $=2$

FIgURE 11: Drying shrinkage of AAS mortars $(L / S=0.64)$.

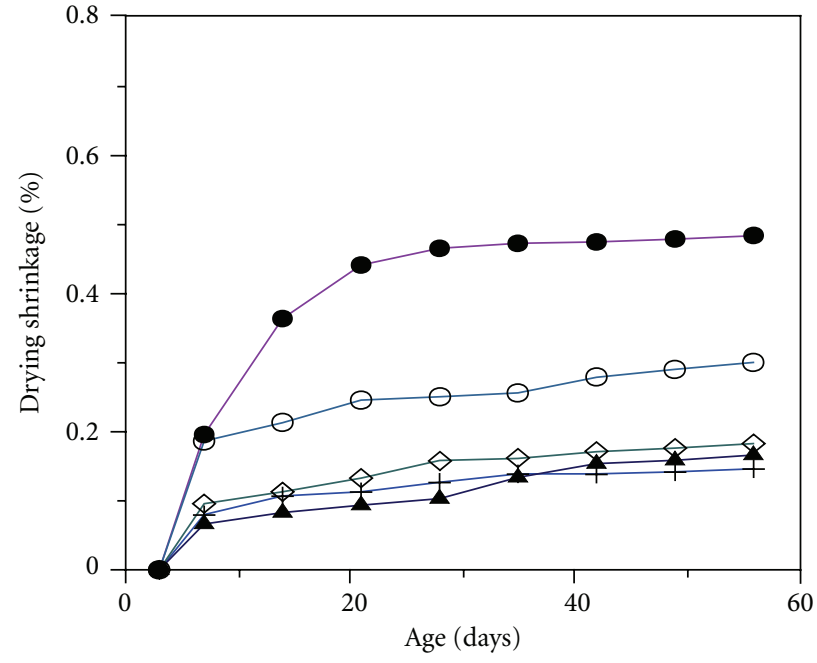

Curing temperature $23^{\circ} \mathrm{C}$

—— Liquid $/$ slag $=0.44 \mathrm{sand} / \mathrm{slag}=2$

$\diamond$ Liquid $/$ slag $=0.54$ sand $/$ slag $=2$

$\bigcirc \mathrm{Liquid} / \mathrm{slag}=0.64 \mathrm{sand} / \mathrm{slag}=2$

+ OPC (water $/$ cement $=0.54 \mathrm{sand} /$ cement $=2$ )

AOPC (liquid/cement $=0.54$ sand/cement $=2$ )

FIGURE 12: Drying shrinkage of AAS and Portland cement mortars.

TABle 4: Drying shrinkage of Portland cement mortars at water/cement ratio of $0.54(\%)$.

\begin{tabular}{lcc}
\hline Group & PC (Portland cement) & $\begin{array}{c}\text { APC (alkali-activated } \\
\text { Portland cement) }\end{array}$ \\
\hline $\begin{array}{l}\text { Curing } \\
\text { temperature }\left({ }^{\circ} \mathrm{C}\right)\end{array}$ & 23 & \\
Sand/slag ratio & & 2 \\
3 days & 0.000 & 0.000 \\
7 days & 0.080 & 0.196 \\
14 days & 0.107 & 0.364 \\
21 days & 0.113 & 0.442 \\
28 days & 0.127 & 0.466 \\
35 days & 0.139 & 0.473 \\
42 days & 0.139 & 0.475 \\
49 days & 0.142 & 0.479 \\
56 days & 0.146 & 0.484 \\
\hline
\end{tabular}

of weight loss of water from the concrete. The pore size distribution and the calcium silicate hydrate gel characteristics have a critical influence on the magnitude of drying shrinkage.

\section{Conclusions}

The results of this paper indicate the following.

(1) Compressive strength is quickly growing with an increase of curing temperature at the age of 3 days. At the age of 56 days, the compressive strength of AAS mortars decreases with an increasing sand/slag ratio and AAS mortars 
show higher compressive strength than Portland cement mortars and alkali-activated Portland cement mortars.

(2) AAS mortars with heat curing for $12 \mathrm{hr}$ at $65^{\circ} \mathrm{C}$ and for $6 \mathrm{hr}$ at $85^{\circ} \mathrm{C}$ show higher tensile strength than the other AAS mortars cured at $23^{\circ} \mathrm{C}$ at 3 and 7 days. As the curing temperature increases from $65^{\circ} \mathrm{C}$ to $85^{\circ} \mathrm{C}$, the tensile strength of AAS mortars has a slow drop. At the age of 56 days, AAS mortars with liquid/slag ratio of 0.54 have the highest tensile strength compared to the other AAS mortars, followed by the liquid/slag ratio of 0.44 and 0.64 .

(3) Most of the drying shrinkage takes place during the early ages. AAS pastes of the drying shrinkage are higher than AAS mortars. Meanwhile, higher drying shrinkage was observed in AAS mortars than that observed in comparable Portland cement mortars.

\section{References}

[1] B. Talling and J. Brandstetr, "Present state and future of alkaliactivated slag concretes," in Proceedings of the International Conference on Fly Ash, Slag, and Natural Pozzolans in Concrete, Trondheim, Norway, 1989.

[2] C. Shi and R. L. Day, "A calorimetric study of early hydration of alkali-slag cements," Cement and Concrete Research, vol. 25, no. 6, pp. 1333-1346, 1995.

[3] A. Fernández-Jiménez, J. G. Palomo, and F. Puertas, "Alkaliactivated slag mortars: mechanical strength behaviour," Cement and Concrete Research, vol. 29, no. 8, pp. 1313-1321, 1999.

[4] T. Bakharev, J. G. Sanjayan, and Y.-B. Cheng, "Alkali activation of Australian slag cements," Cement and Concrete Research, vol. 29, no. 1, pp. 113-120, 1999.

[5] A. A. M. Melo Neto, M. A. Cincotto, and W. Repette, "Drying and autogenous shrinkage of pastes and mortars with activated slag cement," Cement and Concrete Research, vol. 38, no. 4, pp. 565-574, 2008.

[6] A. Gruskovnjak, B. Lothenbach, L. Holzer, R. Figi, and F. Winnefeld, "Hydration of alkali-activated slag: comparison with ordinary Portland cement," Advances in Cement Research, vol. 18, no. 3, pp. 119-128, 2006.

[7] F. Puertas, T. Amat, A. Fernández-Jiménez, and T. Vázquez, "Mechanical and durable behaviour of alkaline cement mortars reinforced with polypropylene fibres," Cement and Concrete Research, vol. 33, no. 12, pp. 2031-2036, 2003.

[8] Z. Vladimir, "Effects of type and dosage of alkaline activator and temperature on the properties of alkali-activated slag mixtures," Construction and Building Materials, vol. 21, no. 7, pp. 1463-1469, 2007.

[9] F. Collins and J. G. Sanjayan, "Strength and shrinkage properties of alkali-activated slag concrete containing porous coarse aggregate," Cement and Concrete Research, vol. 29, no. 4, pp. 607-610, 1999.

[10] D. Krizan and B. Zivanovic, "Effects of dosage and modulus of water glass on early hydration of alkali-slag cements," Cement and Concrete Research, vol. 32, no. 8, pp. 1181-1188, 2002.

[11] T. Bakharev, J. G. Sanjayan, and Y.-B. Cheng, "Effect of elevated temperature curing on properties of alkali-activated slag concrete," Cement and Concrete Research, vol. 29, pp. 1619$1625,1999$.

[12] T. Bakharev, J. G. Sanjayan, and Y.-B. Cheng, "Resistance of alkali-activated slag concrete to acid attack," Cement and Concrete Research, vol. 33, no. 10, pp. 1607-1611, 2003.
[13] S. Fathollah and H. A. Razak, "The effect of chemical activators on early strength of ordinary Portland cement-slag mortars," Construction and Building Materials, vol. 24, no. 10, pp. 1944-1951, 2010.

[14] S.-D. Wang and K. L. Scrivener, "Hydration products of alkali activated slag cement," Cement and Concrete Research, vol. 25, no. 3, pp. 561-571, 1995.

[15] F. Pacheco-Torgal, J. Castro-Gomes, and S. Jalali, "Alkaliactivated binders: a review-part 1 . Historical background, terminology, reaction mechanisms and hydration products," Construction and Building Materials, vol. 22, no. 7, pp. 13051314, 2008.

[16] A. R. Brough and A. Atkinson, "Sodium silicate-based, alkaliactivated slag mortars-part I. Strength, hydration and microstructure," Cement and Concrete Research, vol. 32, no. 6, pp. 865-879, 2002.

[17] M. Khalil and E. Merz, "Immobilization of intermediate-level wastes in geopolymers," Journal of Nuclear Materials, vol. 211, no. 2, pp. 141-148, 1994.

[18] F. Collins and J. G. Sanjayan, "Effect of pore size distribution on drying shrinkage of alkali-activated slag concrete," Cement and Concrete Research, vol. 30, no. 9, pp. 1401-1406, 2000. 

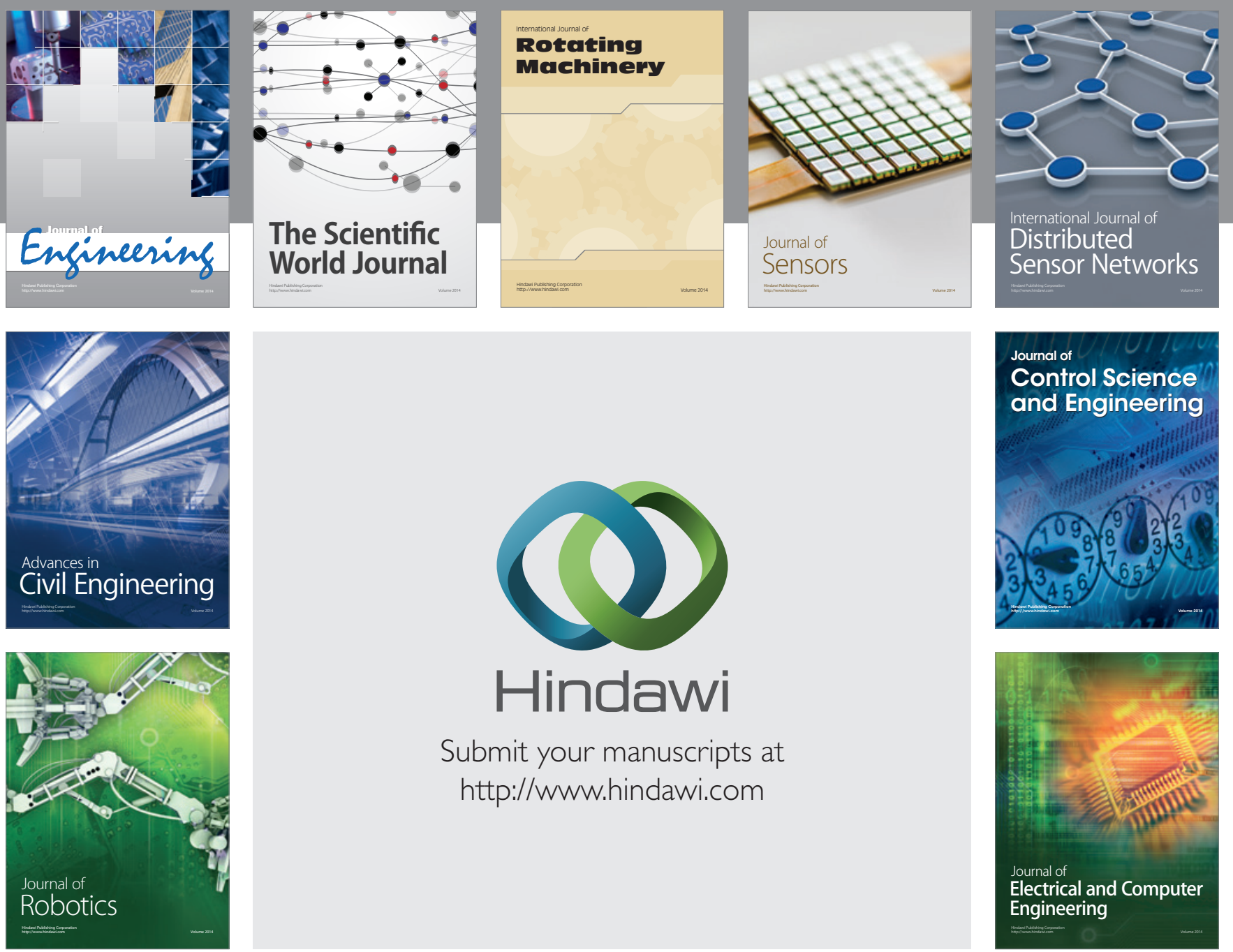

Submit your manuscripts at

http://www.hindawi.com
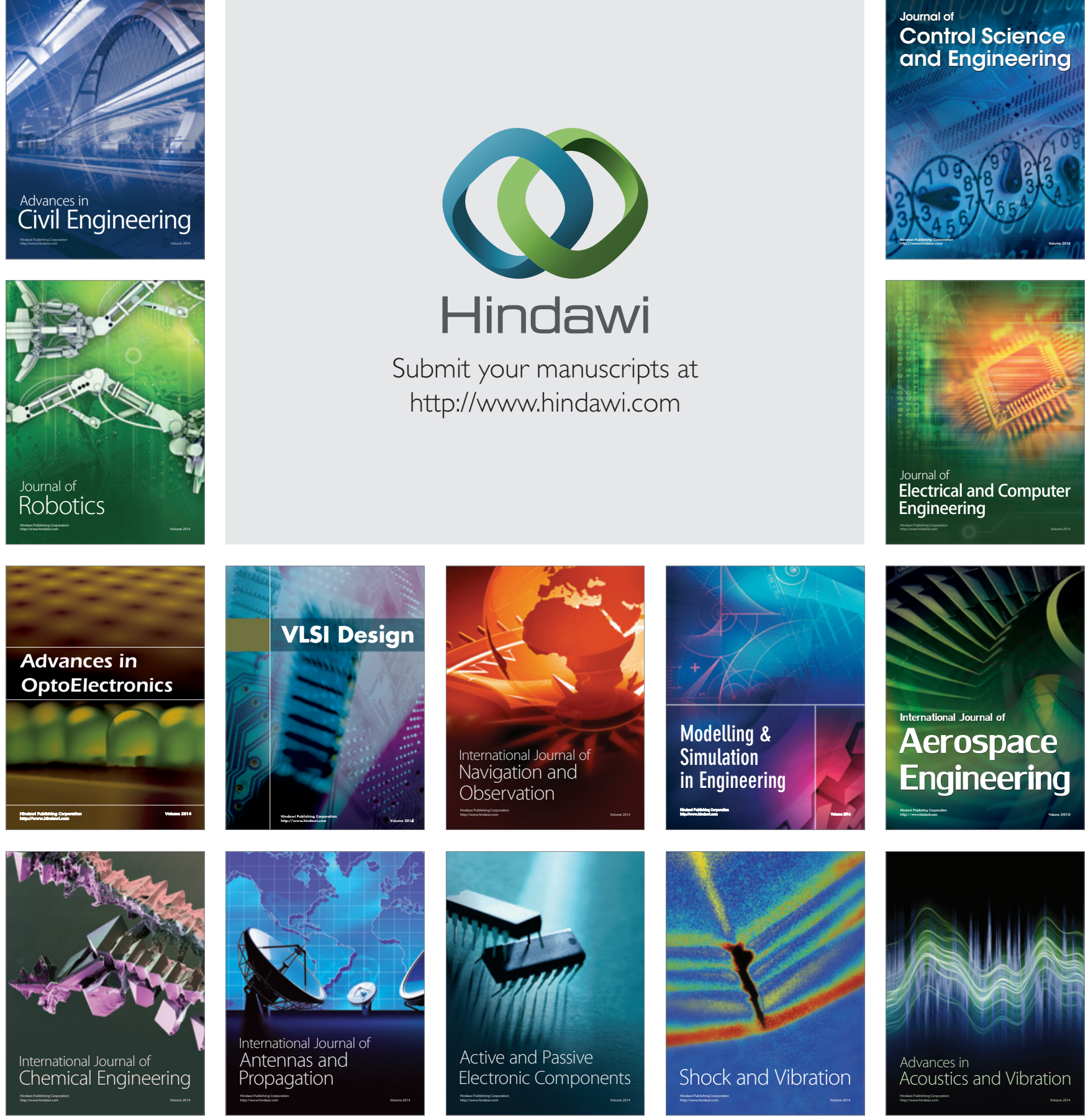